\title{
Description of ichthyosaur remains from the Lower Cretaceous Agrio Formation (Neuquén Basin, west-central Argentina) and their paleobiological implications
}

\author{
Darío G. Lazo ${ }^{\text {a, b, * }, ~ M a r i a n e l l a ~ T a l e v i ~}{ }^{\text {b, c }}$, Cecilia S. Cataldo ${ }^{\text {a, b }}$, Beatriz Aguirre-Urreta a, b \\ Marta S. Fernández b, d \\ a Instituto de Estudios Andinos “Don Pablo Groeber”, Departamento de Ciencias Geológicas, Facultad de Ciencias Exactas y Naturales, Universidad de Buenos \\ Aires, Pabellón II, Ciudad Universitaria, C1428EGA Buenos Aires, Argentina \\ b CONICET, Consejo Nacional de Investigaciones Científicas y Técnicas, Godoy Cruz 2290, C1425FOB Buenos Aires, Argentina \\ c Instituto de Investigación en Paleobiología y Geología, Universidad de Río Negro, Av. Roca 1242, R8332EXZ General Roca, Río Negro, Argentina \\ d División Paleontología de Vertebrados, Museo de La Plata, Universidad Nacional de La Plata, Paseo del Bosque s/n, B1900FWA La Plata, Argentina
}

\section{A R T I C L E I N F O}

\section{Article history:}

Received 17 October 2017

Received in revised form

26 January 2018

Accepted in revised form 27 February 2018

Available online 6 March 2018

\section{Keywords:}

Platypterygiinae

Taphonomy

Facies

Valanginian

Hauterivian

Argentina

\begin{abstract}
A B S T R A C T
Ichthyosaur remains from the Lower Cretaceous of the Neuquén Basin, west-central Argentina, are herein described and put into the broader context of their mode of occurrence and facies relationships. The ichthyosaur material was collected from six stratigraphic levels within the Agrio Formation. Five records come from upper Valanginian black and dark-gray shales, and one comes from upper Hauterivian finegrained grayish sandstones. According to current paleogeographic schemes, all the studied ichthyosaur localities had a distal position on the marine shelf of the Agrio Formation, i.e., towards the offshore and basin. Ichthyosaurs were recorded in second-order TST and HST deposits, being better preserved in black shales of the TST. The best preserved material is a series of seven partially articulated posterior thoracic vertebral centra along with an ischiopubis (plus femur?) of an adult individual found in close association with a partially articulated fin and phalanges of a perinatal specimen. This finding might provide evidence of viviparity and also would indicate that at least some ichthyosaurs were able to pass through the volcanic arc from the Pacific Ocean to reproduce and give birth in an epeiric sea (the Neuquén Basin), similarly to what some large marine mammals do in the present. Given that the upper Valanginian -Hauterivian is particularly devoid of ichthyosaur records worldwide, the remains herein presented can shed light on the Early Cretaceous distribution of these marine reptiles in the Southern Hemisphere. The apparent local absence of ichthyosaurs from Berriasian-middle Valanginian deposits may be due to the overall prevalence of shallower settings in the Neuquén Basin in this time window that deterred the entrance of ichthyosaurs from the open ocean.
\end{abstract}

() 2018 Elsevier Ltd. All rights reserved.

\section{Introduction}

Ichthyosaurs were a highly successful group of reptiles that evolved an obligatory aquatic mode of life. Among Mesozoic marine reptiles, fish-shaped ichthyosaurs were the group that acquired the

\footnotetext{
* Corresponding author. Instituto de Estudios Andinos "Don Pablo Groeber", Departamento de Ciencias Geológicas, Facultad de Ciencias Exactas y Naturales, Universidad de Buenos Aires, Pabellón II, Ciudad Universitaria, C1428EGA Buenos Aires, Argentina.

E-mail addresses: dlazo@gl.fcen.uba.ar (D.G. Lazo), mtalevi@unrn.edu.ar (M. Talevi), ceciliacataldo@gl.fcen.uba.ar (C.S. Cataldo), aguirre@gl.fcen.uba.ar (B. Aguirre-Urreta), martafer@fcnym.unlp.edu.ar (M.S. Fernández).
}

highest level of aquatic adaptation. Anatomical traits associated with these adaptations include streamlined bodies with lunate tail and dorsal fin. The arrangement of limb bones is also strongly modified, forming fins (Motani, 1999; McGowan and Motani, 2003). Their evolutionary history spans most of the Mesozoic, from the Olenekian (Early Triassic) to the Cenomanian (Late Cretaceous) (Bardet, 1994; Fischer et al., 2011a,b, 2014). The youngest and most derived clade, the Ophthalmosauridae, dominated soon after its appearance in the early Bajocian, becoming diverse and geographically widespread (Fernández, 2003; Bardet et al., 2014; Druckenmiller and Maxwell, 2014). Knowledge about ophthalmosaurids increased significantly during the last decade 
(e.g., Fernández and Campos, 2015). However, hiatuses in their fossil record and scarcity of well-preserved materials from certain time intervals and/or geographic regions prove that further sampling is necessary to achieve a better understanding of the evolution of the group. In particular, records from the Valanginian-Hauterivian time lapse are still comparatively scant, with most studies alluding to undetermined remains due to an overall low completeness of records. Some exceptional records in this time interval include a rostrum of Aegirosaurus sp. from the late Valanginian of France (Fischer et al., 2011a), the type materials of Acamptonectes densus Fischer et al., 2012 from the Hauterivian of England and paratype and associated specimens from Germany. A recent completeness metric analysis shows that there are significant drops in species diversity and number of collections after the Jurassic/Cretaceous ( $\mathrm{J} /$ $\mathrm{K}$ ) boundary until a relatively small spike in the Albian (Cleary et al., 2015). However, new findings from the J/K boundary of Svalbard, Norway, have challenged this proposal (Delsett et al., 2017).

Reports of South American ichthyosaurs have been considered as rare (Stinnesbeck et al., 2014). However, there are significant findings from the Middle and Upper Jurassic of the Neuquén Basin. Although not abundant, early Middle Jurassic ichthyosaurs have been recovered that can be considered as outstanding as they represent the only ichthyopterygian records of this epoch from the Eastern Pacific including also the oldest diagnostic record of an ophthalmosaurid worldwide (Fernández, 2003) and some of the few diagnostic Aalenian-Bajocian ichthyosaurs: Stenopterygius cayi (=Chacaicosaurus cayi Fernández, 1994) and Mollesaurus periallus Fernández, 1999. Perhaps the most abundant and diverse ichthyosaur assemblage is the one recovered from Tithonian beds of the Vaca Muerta Formation (Neuquén Basin, Argentina), including at least three nominal taxa: Arthropterygius sp., Aegirosaurus sp. and Caypullisaurus bonapartei (Fernández, 2007; Fernández and Maxwell, 2012). Further south there are records of Early Cretaceous ichthyosaurs from Argentina and Chile. On the one hand, "Platypterygius" hauthali (von Huene, 1927) is known from the Barremian Río Belgrano Formation, Santa Cruz Province, Austral Basin of Argentina (Fernández and Aguirre-Urreta, 2005). On the other hand, a unique concentration of ophthalmosaurid skeletons has been recently recovered from bathyal to abyssal deposits of Valanginian-Hauterivian age (Stinnesbeck et al., 2014) in the Torres del Paine National Park of Chile. This assemblage comprises a total of 46 articulated and virtually complete adult, juvenile, embryonic, and neonate specimens (see also Pardo Pérez et al., 2015).

In this paper, new records of Lower Cretaceous ichthyosaurs from the Agrio Formation (Neuquén Basin) are studied. The Agrio Formation is a thick unit encompassing relatively shallow-marine deposits accumulated in a large epeiric sea connected to the Pacific Ocean during the Valanginian-Hauterivian. The ichthyosaur remains herein presented were collected from six stratigraphic levels that were accurately dated using the associated ammonoid fauna. Disarticulated but associated vertebral centra comprise most of the findings, but more complete postcranial remains, including one ischiopubis (plus femur?) and perinatal fin remains, were also recovered.

The study material was obtained while sampling for mollusks and other invertebrates in the Agrio Formation. It may not therefore be representative of the true diversity of ichthyosaurs present during the Valanginian-Hauterivian in the Neuquén Basin, but it is important to note that they resulted from more than 20 years of exploration and research in the unit and thus they are likely the best approximation to the actual diversity because of the intensive exploration and many years of collecting effort. Despite skeletal incompleteness and poor preservation, these records are important because they partially fill a significant gap in the ichthyosaur evolutionary history, since there are just a few records of this time interval worldwide. Moreover, they also bear importance in terms of local sedimentary evolution, paleoenvironments and paleoecology of the Neuquén Basin through the Valanginian-Hauterivian. The new findings are herein discussed in a sequence stratigraphy framework for the Agrio Formation, comparing their distribution with that of previous plesiosaurian records from the same unit (O'Gorman et al., 2015).

Therefore, the objectives of the present contribution are as follows: 1) to describe and identify to the lowest possible taxonomic rank the new ichthyosaur material; 2) to provide accurate chronostratigraphic ages for these remains based on a refined ammonoid zonation; 3 ) to describe and interpret the taphonomic mode and the facies relationships of the fossil-bearing beds; and 4) to discuss the distribution of the ichthyosaur records in a sequence stratigraphy framework and compare it with that of local plesiosaur records.

\section{Geological setting}

\subsection{The Neuquén Basin and the Agrio Formation}

The Neuquén Basin is located near the present international Argentine-Chilean border along the Andes, roughly between $32^{\circ}$ and $40^{\circ} \mathrm{S}$. The basin covers an area of over $120,000 \mathrm{~km}^{2}$, being represented by a narrow belt of outcrops with a trend parallel to the Andes mainly in Mendoza, and by an eastern expansion known as the Neuquén Embayment developed in the homonymous province (Fig. 1; Howell et al., 2005).

The basin was a back-arc depocenter during Early Jurassic-Early Cretaceous times, developed under active convergence in the western margin of South America. Deposition progressed under the influence of a well-developed volcanic arc. The subsidence regime was rather constant, suggestive of thermal drive. The paleoceanographic connection was towards the Pacific Ocean. Alternating marine and continental deposits accumulated in the basin driven by periodic transgressions. A broadly triangular epeiric sea embayment was formed during times of high relative sea level.

The studied ichthyosaur remains were recovered from the Agrio Formation, a unit defined by Weaver (1931) in the Río Agrio section (Neuquén Province), where it reaches more than $1000 \mathrm{~m}$ in thickness and includes three members. The lower or Pilmatué Member is mainly composed of massive clayey shales interbedded with thin layers of sandstones and shell beds, and has been interpreted mainly as a marine shelf (or ramp) with storm influence to a basinal setting towards the west and north (Fig. 1). The middle or Avilé Member, a thin continental unit, is represented by yellowishbrown cross-bedded sandstones of aeolian and fluvial origin, representing a second-order sea-level fall. The upper or Agua de la Mula Member is composed largely of massive shales in the lower part and gray calcareous shales interbedded with sandstones, sandy limestones and shell beds in the upper part, and represents a new marine transgression (Leanza et al., 2005; Spalletti et al., 2011). Comprehensive accounts of the lithofacies, paleoecology and paleoenvironments of the Agrio Formation can be found in Lazo (2006, 2007) and Spalletti et al. (2011).

The Agrio Formation has a rich and abundant fossil record, first described in detail by Weaver (1931), mainly comprising invertebrates such as bivalves, gastropods, nautiloids, ammonites, corals, crustaceans, echinoderms, bryozoans, brachiopods, and serpulids (Aguirre-Urreta et al., 2011). The invertebrate fauna as a whole has mainly Tethyan affinity, but some taxa have Andean affinity and even endemic taxa are present (Aguirre-Urreta et al., 2008; Cataldo, 2017). The invertebrates also indicate shallow warm-temperate waters (Lazo et al., 2005).

Marine reptiles have been scarcely recorded in the unit, corresponding to mainly disarticulated postcranial remains of plesiosaurs. 


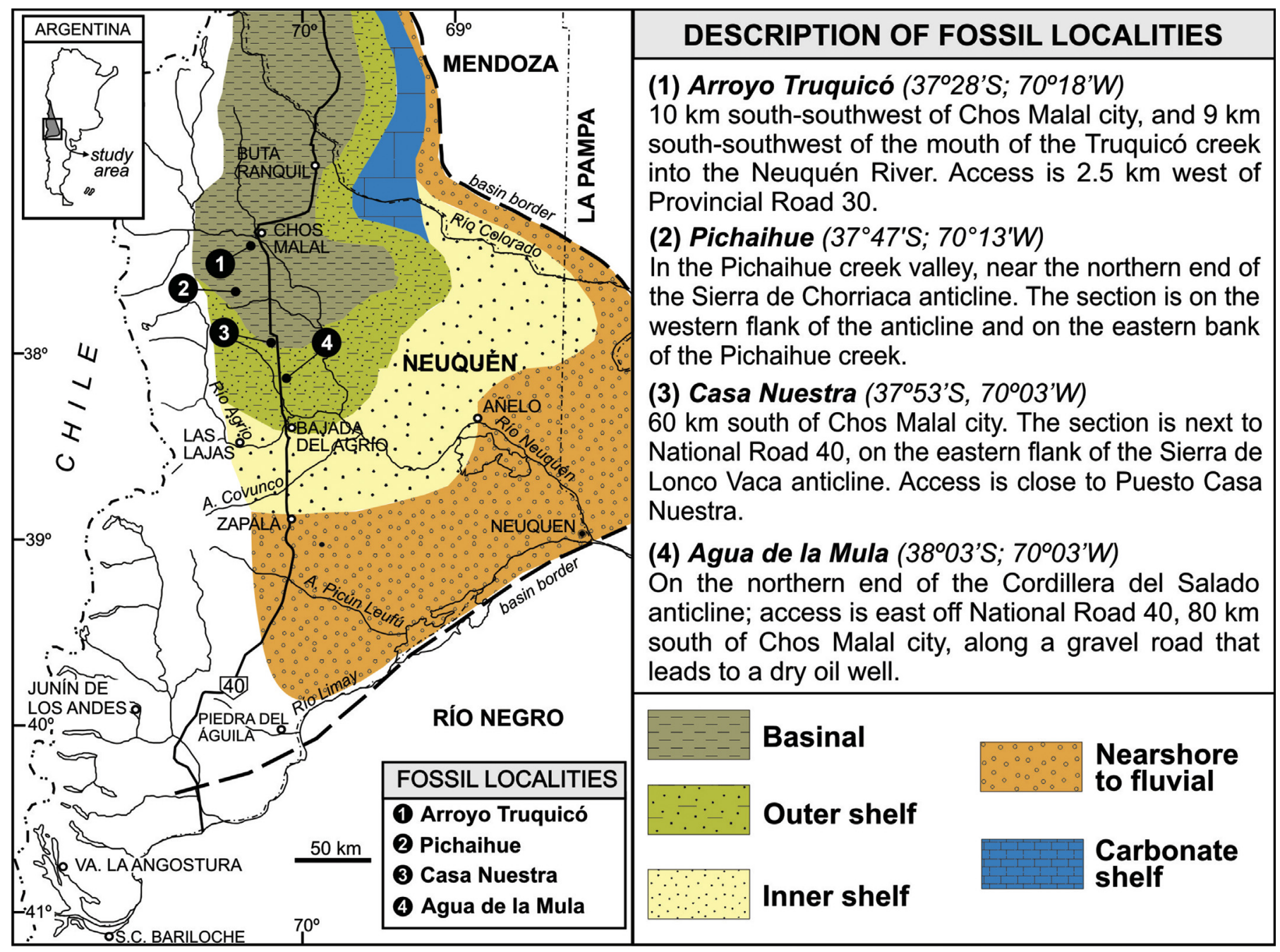

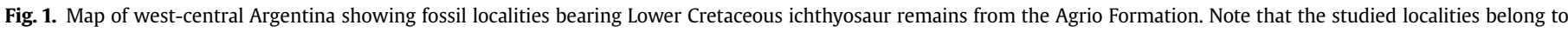
the distal sector of the basin, from outer shelf to basin. Paleogeography and facies from Legarreta and Uliana (1991).

Most of these findings belong to long-necked elasmosaurids recorded in both marine members of the Agrio Formation encompassing the Valanginian-Hauterivian interval (O'Gorman et al., 2015). Ichthyosaur remains are extremely rare in the unit, so far represented by disarticulated, isolated and fragmented vertebral centra only (see Cichowolski and Lazo, 2000). In the present study, however, more complete and partially articulated postcranial remains are described along with several isolated vertebral centra. A preliminary report of these records was published by Fernández et al. (2015). The studied materials come from both marine members of the Agrio Formation, i.e., the Pilmatué and the Agua de la Mula members (Fig. 2, Table 1).

Integrated studies on ammonoids, nannofossils and palynomorphs from the Agrio Formation have provided an excellent biostratigraphic framework for the unit that can be easily followed from one locality to another (see Aguirre-Urreta and Rawson, 2010, 2012; Aguirre-Urreta et al., 2005, 2007). The zonation is also correlated with the Standard Ammonoid Zonation of the Mediterranean Region of Western Europe (Aguirre-Urreta et al., 2007). The whole unit has been assigned a late early Valanginian to late Hauterivian age based on integrated biostratigraphy calibrated with U-Pb zircon ages (e.g., Aguirre-Urreta et al., 2015, 2017).

The studied ichthyosaur remains were collected at four localities. From north to south these are: 1) Arroyo Truquicó, 2) Pichaihue, 3)
Casa Nuestra, and 4) Agua de la Mula (Fig. 1). These sections are located towards the northern part of Neuquén and thus more distally placed on the marine shelf of the Agrio Formation, belonging to basinal (Arroyo Truquicó and Pichaihue) and outer shelf (Casa Nuestra and Agua de la Mula) settings, respectively (Fig. 1).

\subsection{Sequence stratigraphy framework}

Legarreta and Gulisano (1989) published the first attempt of an analysis of the sedimentary record of the Neuquén Basin using a sequence stratigraphy approach. The framework they proposed, which remains valid (see Veiga et al., 2005 and references therein), included three first-order sequences (also called super sequences) encompassing latest Triassic to Paleocene deposits. The Agrio Formation is included in the middle supersequence, previously referred to as Andean Cycle by Groeber (1946). This cycle is characterized by the overall presence of marine sedimentary deposits, especially black and dark-gray shales, but also by a continuous sedimentation through the Tithonian/Berriasian boundary that resulted in a transitional pass with no obvious contrast between Tithonian and Berriasian sedimentary facies.

The Andean cycle was in turn subdivided into five second-order sequences (also called mesosequences). The Mulichinco Formation and the Pilmatué Member of the Agrio Formation constitute the 


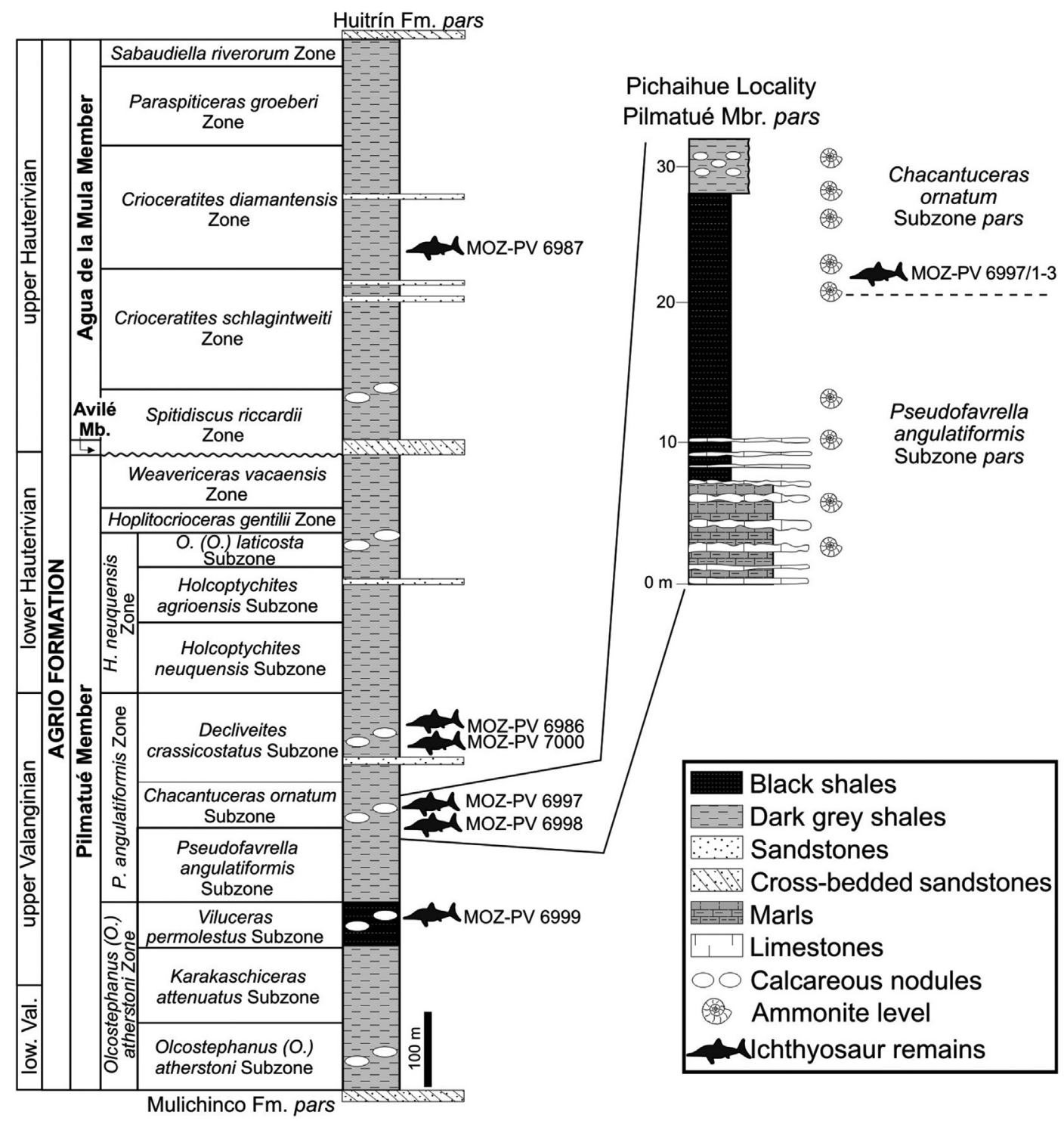

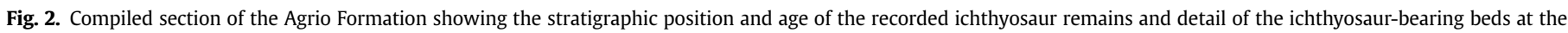
Pichaihue locality. Ammonoid zonation and ages from Aguirre-Urreta et al. (2007) and Aguirre-Urreta and Rawson (2010).

middle Mendoza mesosequence, while the Avilé and Agua de la Mula members compose the upper Mendoza mesosequence. Two regional sequence boundaries depict the base of each mesosequence (Fig. 3): the older one is called the Intravalanginian Discontinuity (Gulisano et al., 1984) while the younger one is called Intrahauterivian Discontinuity (Legarreta and Kozlowski, 1984). Further details on the Intravalanginian Discontinuity and associated systems tracts can be found in Schwarz and Buatois (2012). Each mesosequence has been subdivided, from base to top, into second-order lowstand systems tract (LST), transgressive systems tract (TST) and highstand systems tract (HST). The base of each LST is depicted by the mentioned regional unconformities, which developed during major sea level falls. The LST includes mainly continental deposits in central parts of the basin while the TST and HST deposits are mainly of marine origin. Both the middle and upper Mendoza mesosequences and their division into LST, TST and HST are depicted in Fig. 3. This is the sequence stratigraphy framework used to evaluate the local ichthyosaur records.

The studied ichthyosaur materials and previously published plesiosaur remains from the Agrio Formation are placed in this sequence stratigraphy framework to test for a correlation between sea level, accommodation space and the occurrence of marine reptiles (Fig. 3). The placement of each ichthyosaur/plesiosaur record was easily done by means of the associated ammonoid faunas and the current biostratigraphic zonation scheme. This type of analysis can be useful to interpret the paleoecological traits of ichthyosaurs, but also to evaluate biases in the ichthyosaur fossil record and determine the best localities for further prospection.

\section{Systematic paleontology}

The studied ichthyosaur materials are housed in the following collection under the catalogue numbers listed in the text: MOZ, Museo Juan Olsacher, Zapala, Neuquén, Argentina. Specimens were mechanically prepared. Five of the isolated phalanges of the MOZPV-6997/1, found in association with the articulated fin, were sectioned in order to explore the microstructural and histological pattern. The phalanges (1.2-2.3 cm in length) are roughly rounded and herein identified as belonging to the more distal portion of the fin. Thin sections were prepared using standard paleohistological 


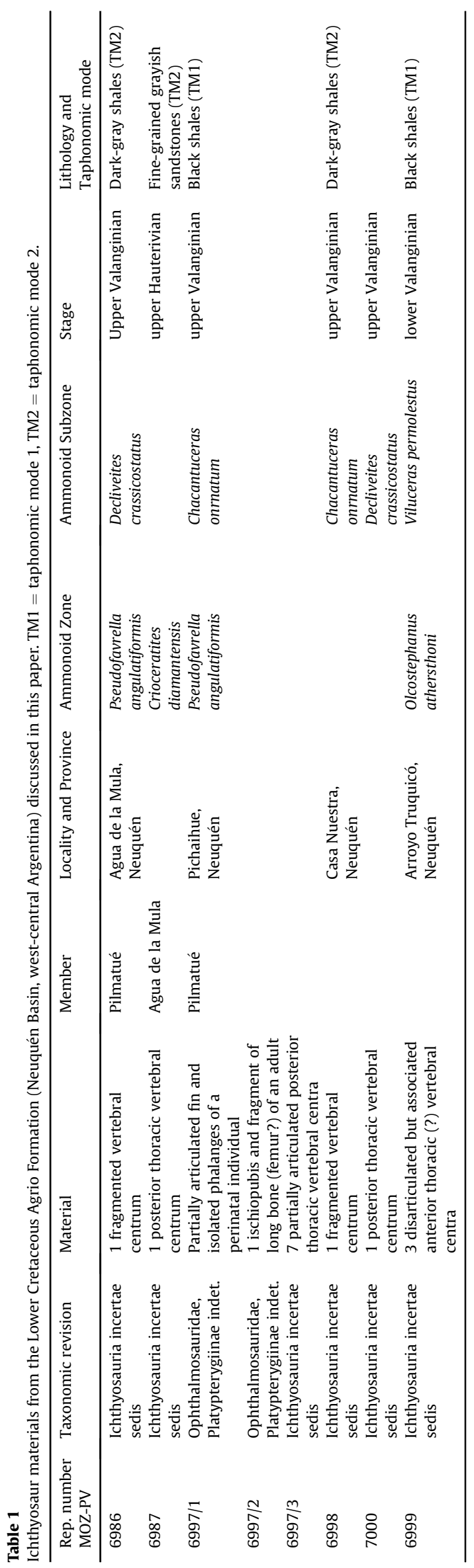

techniques and examined with light microscopy (Chinsamy and Raath, 1992). Nomenclature and definitions of structures used in this study are derived from Chinsamy-Turan (2005) and FrancillonVieillot et al. (1990). Identification of vertebral centra follows Kear (2006), Maisch and Matzke (2000), and Maxwell and Caldwell (2006). All described materials represent adult specimens, except material MOZ-PV-6997/1 that corresponds to a newborn or unborn specimen (= perinatal).

Order Ichthyosauria De Blainville, 1835.

Family Ophthalmosauridae Baur, 1887.

Subfamily Platypterygiinae Arkhangelsky, 2001 sensu Fischer et al., 2012

\section{Platypterygiinae indet. Figs. 4,5}

Material. MOZ-PV-6997/1, partially articulated fin and phalanges of a perinatal specimen (Table 1 ). Geographic and stratigraphic provenance. This material was recovered from the Pilmatué Member of the Agrio Formation at Pichaihue locality, Neuquén, Argentina. It was found loose but associated within a single stratigraphic level of black shales in close association with materials MOZ-PV-6997/2 and MOZ-PV-6997/3. All from the Chacantuceras ornatum Subzone of late Valanginian age (Table 1, Fig. 2).

Description. Eight articulated and several isolated fin elements have been studied. The articulated fin portion consists of three elements not anatomically displaced and mesopodials and phalanges postmortem proximally displaced (Fig. 4). All the elements are plastically deformed. There is a conspicuous difference in the thickness of articulated and isolated elements. All fin elements are relatively small, the largest element (tentatively identified as carpal 3) reaching $30 \mathrm{~mm}$ antero-posteriorly and $23 \mathrm{~mm}$ proximo-distally. Some of them, tentatively interpreted as mesopodials, are as thick dorso-ventrally as they are long proximo-distally. The other elements, interpreted as phalanges, are longer than thick, being the most distal phalanges twice as long as thick. As the epipodium and zeugopodium are not preserved it is difficult to determine the dorso-ventral orientation of the articulated fin fragment. The most proximal element, interpreted as the intermedium, has a roughly hexagonal dorsal or ventral surface and bears two almost straight distal articular facets forming an obtuse angle between them. Distal to it, and naturally articulated with it, there is a pentagonal element that could belong, based on its topological relationship with the intermedium and its outline, to the distal carpal 3. Three elements, almost rectangular in outline, have been preserved articulated and, based on their morphology, are herein interpreted as phalanges. On one side a small round phalange has been preserved partially overlying two of the more proximal articulated phalanges. Isolated elements recovered in association with the articulated fragment comprise five dorso-ventrally thick elements that could correspond to counter lateral mesopodium and phalanges (Fig. 4). Two of them (one with the typical brick-like outline and the other smaller and with a slightly rounder profile) were sectioned for microstructure analysis.

Histology and microstructure of phalanges. Phalangeal sections depict the same internal pattern, so the description and figures correspond to only one of them, i.e., the most proximal one. The inner organization is cancellous and has a thick compact external layer of articular calcified cartilage (Fig. 5A, 5C). There is no open medullary cavity. The medullar region is cancellous, with few cavities separated by relatively thin trabeculae (Fig. 5B, 5D). The trabeculae contain globular shaped osteocyte lacunae with few canaliculi. The trabecular bone, in the inner part of the section, consists of primary bone with woven matrix and contains few 


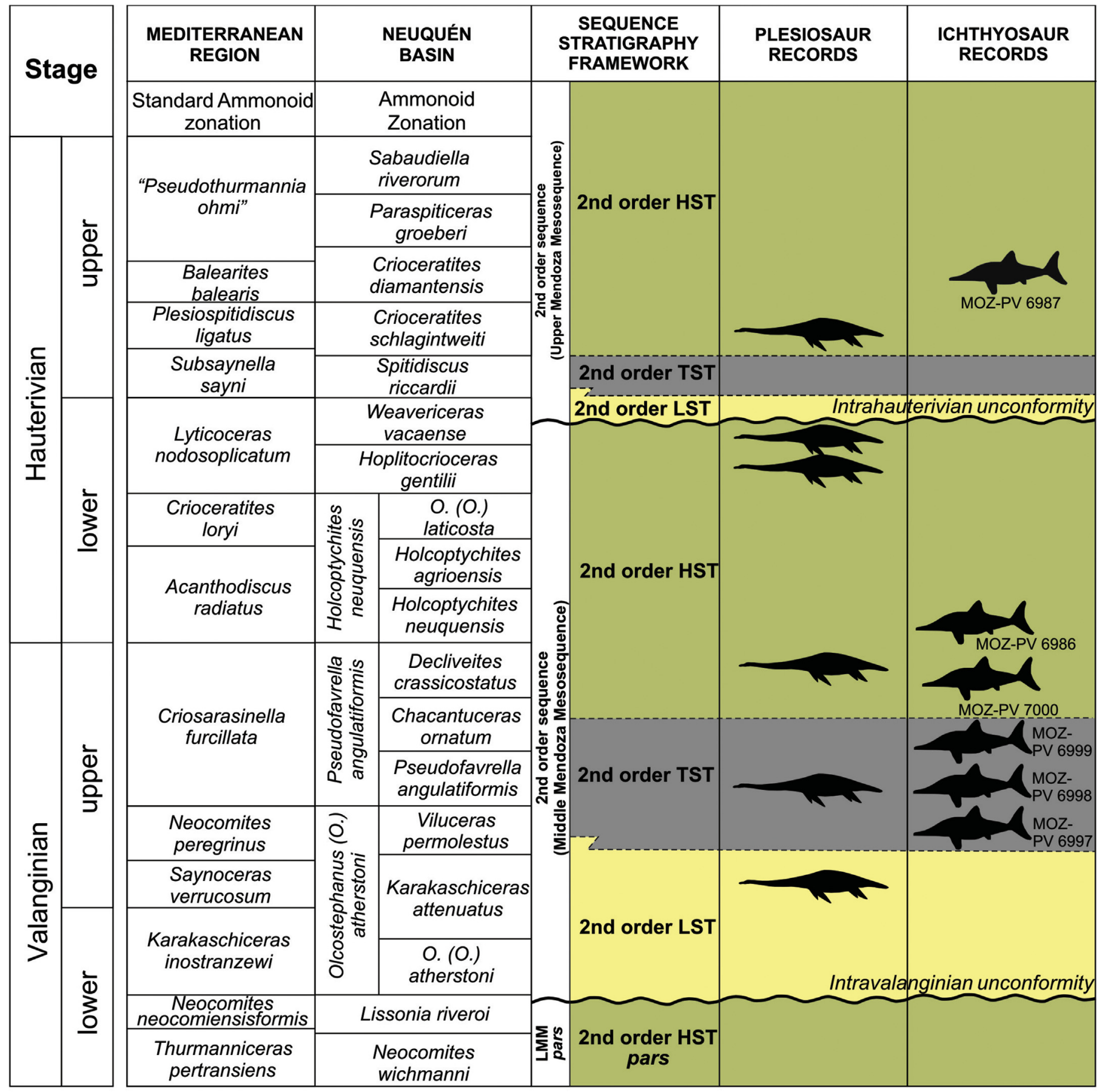

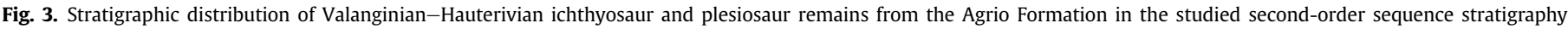

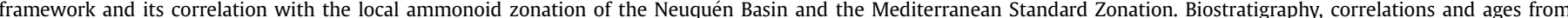

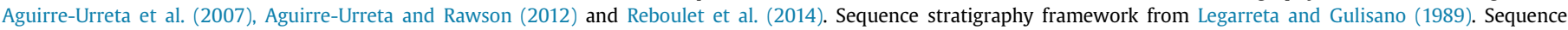

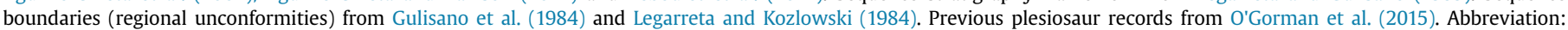
$\mathrm{LMM}=$ lower Mendoza mesosequence.

simple vascular canals. This matrix remains monorefringent in polarized light. This feature reflects the absence of highly orderly spatial organization of the once present collagenous framework of bone tissue. Also in the trabeculae there are remnants of calcified cartilage (Fig. 5D). The calcified cartilage forms $82.63 \%$ of the total area (Fig. 5B). It is not possible to distinguish any sign of remodeling in the bone tissue.

Discussion. The genus Platypterygius von Huene is in need of a major revision. Species included within this genus share the typical "brick-like" phalanges (McGowan and Motani, 2003; Kolb and Sander, 2009; Fischer, 2012), condition also present in other Platypterygiinae such as Caypullisaurus Fernández and Sveltonectes Fischer et al. Fischer (2016) in a revision of European forms assigned to Platypterygius stated that this genus should be restricted to the type species P. platydactylus (Broili, 1907). In this context, the studied MOZ-PV-6997/1 material is referred as Platypterygiinae indet. Even though it is not possible to give a more precise taxonomic identification, it is interesting to note the 

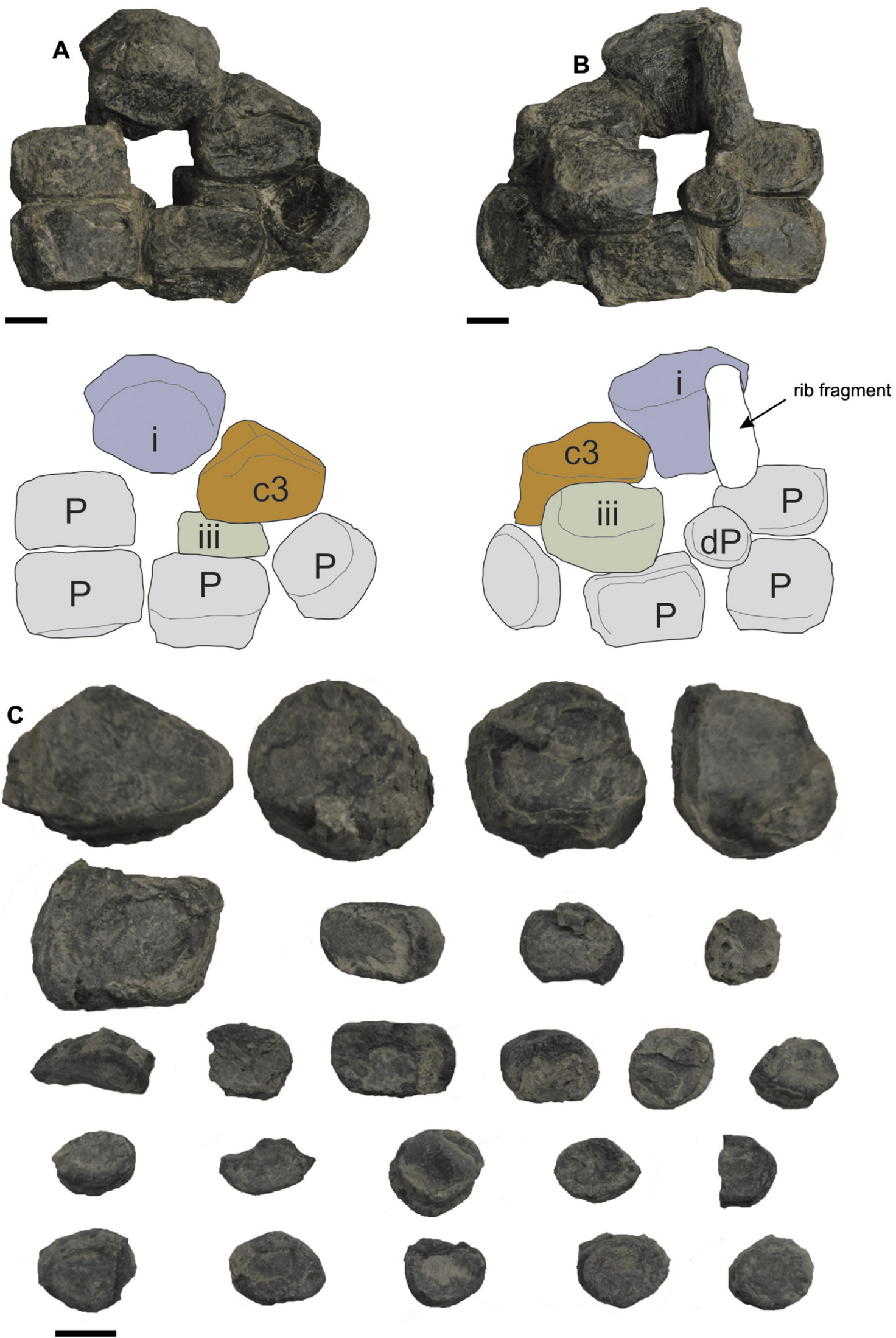

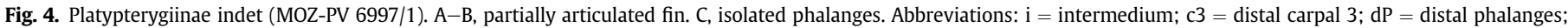

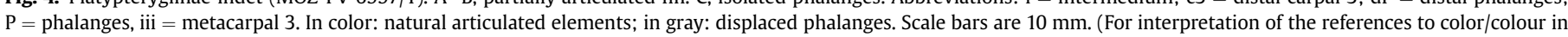
this figure legend, the reader is referred to the Web version of this article.) 

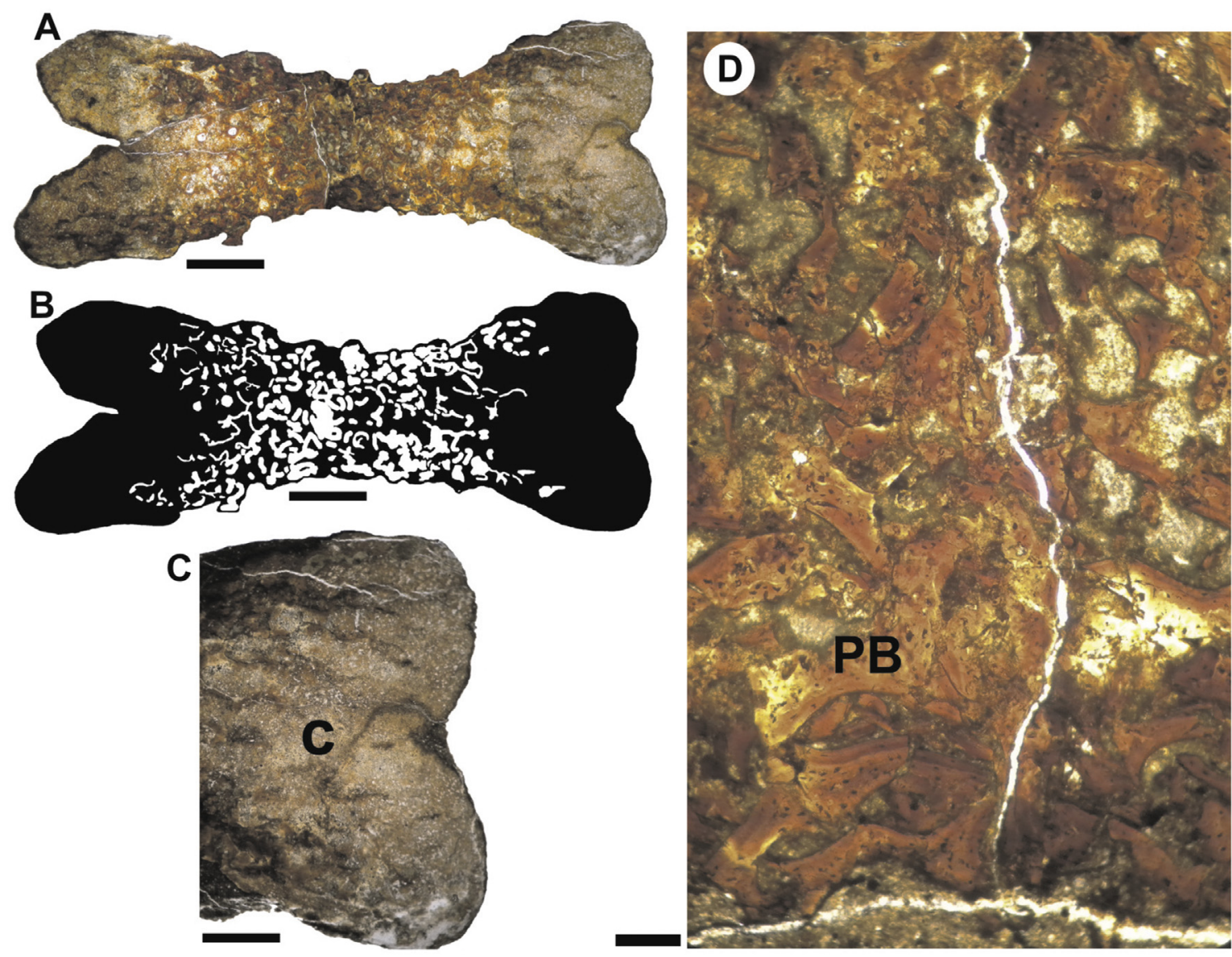

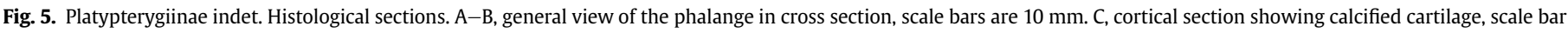
is $10 \mathrm{~mm}$. D, medullary region with trabecular formed of primary bone, scale bar is $250 \mu \mathrm{m}$. Abbreviations: $\mathrm{C}=$ calcified cartilage; $\mathrm{Pb}=$ primary bone.

hexagonal and diamond-shaped intermedium similar to the one described as diagnostic of "Platypterygius" hauthali von Huene, 1927 depicted by Fernández and Aguirre-Urreta (2005).

The most conspicuous feature of the fin is its reduced size. This fact could be interpreted as evidence of small-sized adults or a juvenile. Moreover, bone histology characterized by the predominance of cartilage, primary bone tissue without remodeling signs, the pattern of medullar tissue (i.e., globular shaped osteocyte lacunae, woven fibered bone) and few simple vascular canals, indicates that the bones correspond to a perinatal specimen (sensu Horner et al., 2001). As the bones were not found exactly within the presumed mother rib cage it cannot be determined if they belong to an unborn or a newborn (perinatal) specimen. However, as it is associated with a string of partially articulated posterior thoracic vertebral centra (MOZ-PV-6997/3) it is probably an unborn specimen. Among higher vertebrates, in embryos and in very fast growing young individuals, bone tissue is exclusively formed of a woven matrix (Francillon-Vieillot et al., 1990). The perinatal bone tissue is characterized by a lower organization of tissue and the presence of simple vascular canals (Klein et al., 2015). Woven fibered bone is unambiguously considered as indicative of a high absolute rate (expressed in micrones/day) of periosteal accretion. Indeed, this bone tissue is accreted during the embryonic stage in numerous tetrapods (Francillon-Vieillot et al., 1990).

This finding shows some similarity with the case study of Maxwell and Caldwell (2003), who described articulated though only partially preserved remains of embryonic ichthyosaurs located within the body cavity of an adult, presumably the mother, from the Loon River Formation, Albian of Northwest Territories, Canada. It is worth noting that these authors found the embryos attached to a string of eight mid-thoracic vertebrae (height of $6 \mathrm{~cm}$, width of $2.5 \mathrm{~cm}$ ) from a large adult ichthyosaur, which is very similar to the finding presented herein (i.e., several posterior thoracic vertebral centra-MOZ-PV-6997/3 - of an adult individual associated with phalange elements of a newborn or unborn specimen-MOZ-PV$6997 / 1)$. In spite of its relatively poor preservation, the finding presented here is considered an evidence of ichthyosaur viviparity and it raises an interesting hypothesis related to ichthyosaur reproductive habits implying that oceanic ichthyosaurs were able to enter a back-arc basin from the Eastern Pacific Ocean to reproduce and give birth in epeiric seas, closer to the coast, in a similar way to what some large marine mammals do in the present. However, more evidence on juvenile versus adult specimens is needed to test if the Neuquén Basin was a true reproductive area for ichthyosaurs.

Embryos of $P$. hauthali von Huene have also been found in the Valanginian-Hauterivian of southern Chile (Stinnesbeck et al., 2014, Table 1: specimen TY56), as well as neonates (Stinnesbeck et al., 2014, Table 1: specimens: TY01, TY36 and CPAP0002) among a total of 46 articulated ichthyosaurs, supporting the hypothesis of ichthyosaur viviparity and the use of a back-arc basin to reproduce. The Chilean locality at Tyndall (Rocas Verdes Basin) was also suggested as an ichthyosaur reproductive area (Stinnesbeck et al., 2014). These findings altogether reinforce the hypothesis that ichthyosaurs used protected areas for reproduction.

\section{Platypterygiinae indet.}

Fig. 6 


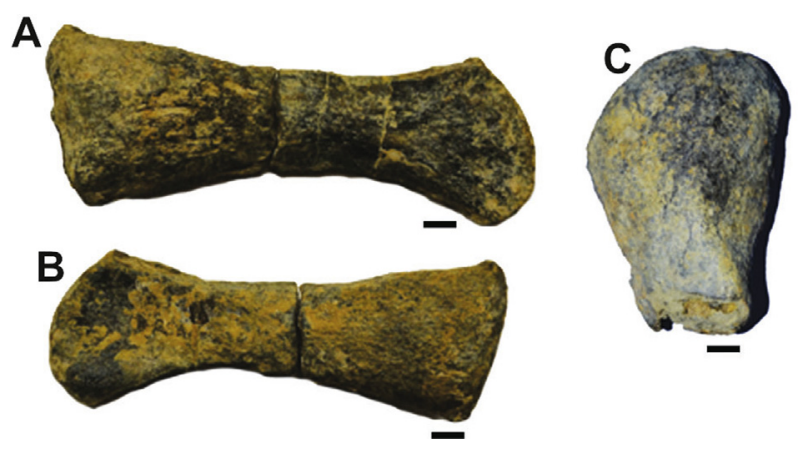

Fig. 6. Platypterygiinae indet (MOZ-PV 6997/2). A-B, ischium and pubis completely fused, forming an ischiopubis, note distal portion strongly compressed. C, fragment of a long bone (femur?). Scale bars are $10 \mathrm{~mm}$.

Material. MOZ-PV-6997/2, an isolated ischiopubis and a fragment of long bone (femur?) (Table 1 ).

Geographic and stratigraphic provenance. This material comes from the Pilmatué Member of the Agrio Formation at Pichaihue locality, Neuquén, Argentina. It was found loose in black shales of the Chacantuceras ornatum Subzone of late Valanginian age (Fig. 2), closely associated with materials MOZ-PV 6997/1 and MOZ-PV$6997 / 3$.

Description. The ischium and pubis are completely fused, forming an ischiopubis with no trace of an obturator foramen. Its proximodistal length is $124 \mathrm{~mm}$. As in all other platypterygiines, this ischiopubis is a rod-like structure for most of its length. Its anterior edge is slightly thicker than the posterior one. Both the acetabular and medial ends are almost equally antero-posteriorly expanded (maximum antero-posterior acetabular length $=45 \mathrm{~mm}$; maximum antero-posterior medial length $=43 \mathrm{~mm}$ ). Its proximal portion is thickened, ending in an ovoid rugose acetabular facet. Its distal portion is strongly compressed (Fig. 6A, B). There is an isolated fragment of a long bone poorly preserved (Fig. 6C) that could correspond to a femur fragment.

Discussion. The MOZ-PV-6997/2 shares the fused ischiopubis with the rest of the Baracromia clade (Fischer et al., 2013). Within this clade, it shares with the Platypterygiinae one of its unambiguous synapomorphies: the lack of an obturator foramen (Fischer et al., 2012, character 45). Morphology of the pelvic girdle is not known and/or described in ophthalmosaurids. In a recent contribution on the evolution of the Ichthyopterygian pelvic girdle, information on the ischiopubis is only available for 11 taxa among 23 ophthalmosaurids (Delsett et al., 2017). Although the information on the pelvic girdle is incomplete, a striking feature of the MOZ-PV$6997 / 2$ is that, contrary to the condition known in all other ophthalmosaurids, the medial and acetabular ends of the ischiopubis are almost equally antero-posteriorly expanded.

\section{Ichthyosauria incertae sedis}

Fig. 7

Material. MOZ-PV-6986, one fragmented vertebral centrum; MOZPV-6987, one posterior thoracic vertebral centrum; MOZ-PV-6997/ 3 , seven partially articulated posterior thoracic vertebral centra; MOZ-PV-6998, one fragmented vertebral centrum; MOZ-PV-6999, three disarticulated but associated anterior thoracic (?) vertebral centra; and MOZ-PV-7000, one posterior thoracic vertebral centrum (Table 1). MOZ-PV-6997/3 was found in close association with MOZ-PV-6997/1 (partially articulated fin) and MOZ-PV-6997/ 2 (ischiopubis) in a single interval of black shales of the Pilmatué Member at Pichaihue locality, Neuquén, Argentina.
Geographic and stratigraphic provenance. These vertebral centra come from a variety of facies of the Pilmatué and Agua de la Mula members of the Agrio Formation at Arroyo Truquicó, Casa Nuestra and Agua de la Mula localities, Neuquén, Argentina. They were found in the Olcostephanus (O.) atherstoni, Pseudofavrella angulatiformis and Crioceratites diamantensis zones, encompassing the lower Valanginian to upper Hauterivian (for further details see Table 1 and Fig. 2).

Description. MOZ-PV-6986 and MOZ-PV-6998 are two poorlypreserved fragmented vertebral centra and thus difficult to identify. They are round and biconcave (amphicœlous). In particular, MOZ-PV-6986 shows diapophyses and parapophyses located low on the centrum, near the ventral region and thus it possibly represents a posterior thoracic or an anterior caudal vertebra.

MOZ-PV-6987 (Fig. 7C) probably represents a single posterior thoracic vertebral centrum (sensu Maisch and Matzke, 2000, fig. 19). It is a narrow, biconcave (amphicœlous), ovoid centrum; diapophyses and parapophyses are not distinguishable from each other, but placed close to the ventral margin.

MOZ-PV-6997/3 represents a series of seven partially articulated posterior thoracic vertebral centra (sensu Maisch and Matzke, 2000, fig. 19). These vertebral centra are narrow, biconcave discs (amphicœlous), slightly elongated in dorsoventral direction; diapophyses and parapophyses, small and subcircular, are located low on the centrum near the ventral region, close to each other, but still separated and close to the anterior face of the centrum (Fig. 7A-B, EF). The ventral surface is smooth and round; the dorsal surface shows two straight, deep ovoid notches for articulation of the neural arch; the anterior and posterior surface margins form a low angle with the lateral centrum sides; neural arches and spines are lost but dorsal articulation face is noticeable and subrectangular. On two of the centra there is a phalange and a rib fragment still attached (Fig. 7A-B).

MOZ-PV-6999 comprises three vertebral centra; all of them are narrow, biconcave discs (amphicœlous); one of them shows diapophyses close to the articulation of the neural arch and parapophyses placed lower on the centrum and thus it could represent an anterior thoracic vertebra; the anterior and posterior surface margins form a low angle with the lateral centrum sides; neural arches and spines are lost.

MOZ-PV-7000 is an isolated posterior thoracic vertebral centrum (sensu Maisch and Matzke, 2000, fig. 19). It is a narrow, biconcave disc (amphicœlous), slightly elongated in dorsoventral direction; diapophyses and parapophyses are located low on the centrum near the ventral region; neural arches and spines are lost. Discussion. All of the vertebral features observed in the studied materials are compatible with those observed on vertebrae from post-Triassic ichthyosaurs. Unfortunately, poorly preserved isolated vertebrae preclude a more precise identification, which would be very interesting from an evolutionary point of view, given the overall scarcity of Early Cretaceous ichthyosaur remains worldwide (Fischer et al., 2011a,b).

The most informative material is MOZ-PV-6997/3, which was found partially articulated and in close association with MOZ-PV$6997 / 1$ and $6997 / 2$ and thus may be referred to Platypterygiinae.

\section{Mode of occurrence and facies relationships}

\subsection{Methods}

A general stratigraphic section of the Agrio Formation, approximately $1200 \mathrm{~m}$ in thickness, was measured at the Agua de la Mula locality (Fig. 2). This section along with partial ones from Arroyo Truquicó and Pichaihue localities (Fig. 2) were used to plot all 

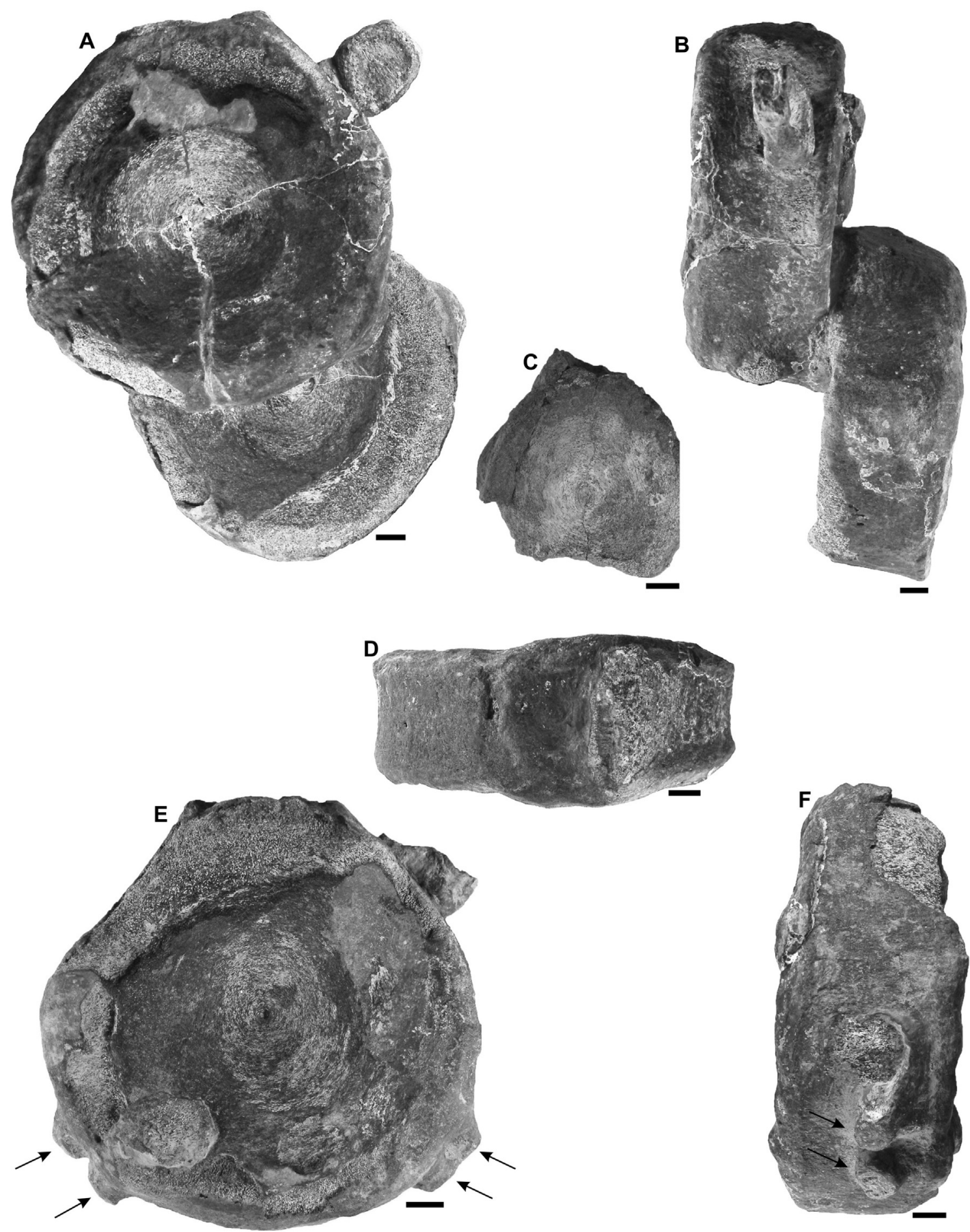

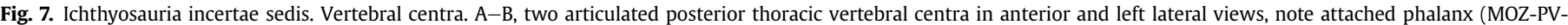

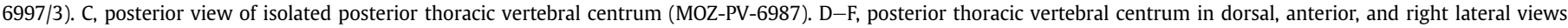
(MOZ-PV-6997/3). Arrows point to diapophyses and parapophyses. Scale bars are $10 \mathrm{~mm}$.

ichthyosaur records of the Agrio Formation from the studied localities corresponding to the upper Valanginian-upper Hauterivian. In particular, a bed-by-bed log of MOZ-PV-6997/1-3 bearing beds was performed at Pichaihue locality to study facies relationships and taphonomic modes of the recorded ichthyosaur remains. This locality was selected because it yielded the bestpreserved material including the perinatal specimen. The studied ichthyosaur remains can be divided into two taphonomic modes taking into account taphonomic observations and the fossil-bearing facies (see 4.2 and 4.3 ).

In all cases, lithofacies and sedimentary cycles were characterized in the field taking into account geometry, lithology, sedimentary structures and fossil content. In addition, taphonomic features were qualitatively described in the field based on the general taphonomic guidelines proposed by Behrensmeyer (1991). Cyclicity of deposits and sequence stratigraphy framework of the 
Mulichinco and Agrio formations follow the proposals of Legarreta and Gulisano (1989), Schwarz and Howell (2005), Schwarz and Buatois (2012) and Spalletti et al. (2001).

\subsection{Taphonomic mode 1: partially articulated ichthyosaur remains embedded in black shales}

Description. MOZ-PV-6997/1-3 was found in a 20 m-thick interval dominated by tabular monotonous black shales, including paper and massive shales, with subordinated thin levels of tabular black marls and black concretionary mudstones (Fig. 8A-B). Parallel lamination is present with no evidence of bioturbation. Orientation of bones in cross-section is parallel to bedding. The interval has scattered thin levels of calcareous nodules of up to $15 \mathrm{~cm}$ of maximum length oriented parallel to bedding. Ammonites are abundantly recorded, laterally crushed and oriented parallel to the bedding plane (Fig. 8C). Body chambers are usually filled with sedimentary matrix while phragmocones are empty. There are no records of benthic macroinvertebrates.

Ichthyosaur remains MOZ-PV-6997/1-3 were found partially disarticulated but closely associated in a small outcrop area in the mentioned interval of monotonous black shales. It is difficult to say if they belonged to more than two individuals, but at least they belonged to one adult individual and one perinatal individual. MOZ-PV-6997/1 includes a partially articulated fin and several phalanges of a perinatal specimen, whilst MOZ-PV-6997/2 is an isolated adult ischiopubis plus a fragmentary long bone (femur?). MOZ-PV-6997/3 belongs to seven partially articulated thoracic vertebral centra of an adult individual. Only isolated rib fragments were recovered, which were left in the field. MOZ-PV-
6999 belongs to three disarticulated but associated anterior thoracic (?) vertebral centra found in black shales at Arroyo Truquicó locality.

Interpretation. This mode of preservation probably resulted from the floating and eventually sinking of carcasses to a muddy and calm seafloor under anoxic conditions, resulting in in situ (autochthonous) preservation without significant transport or physical reworking, except for modern weathering and disarticulation. Carcasses were rapidly embedded by the soft anoxic mud and thus preserved articulated. This allowed the preservation of the delicate remains of a perinatal specimen. The fossil-bearing facies can be interpreted as deposited in a basinal setting with water column stratification and stagnant seafloor. The absence of benthic fauna and bioturbation support the anoxic condition of the basin seafloor. Seafloor anoxia has a significant role in exceptional preservations, however, a combination of anoxia and rapid burial (obrution) is better as anoxia on itself does not prevent decay on the long term (Seilacher et al., 1985; Allison, 1988). This ichthyosaur-bearing facies is very similar to the black shales recorded at the base of the Vaca Muerta Formation (basal transgressive deposits) where abundant Tithonian ichthyosaur material has been collected from different localities. It is also similar to the stagnant basin deposits of the Toarcian bituminous Posidonia Shales of Holzmaden where abundant complete ichthyosaur skeletons have been recovered (Seilacher et al., 1985). This taphonomic mode is consistent with the findings of Cleary et al. (2015) which showed that ichthyosaurs from predominantly fine-grained clastic deposits were the best preserved, followed by those from mixed clastic/ carbonate facies and being those from predominantly carbonate units the worst preserved ichthyosaurs.
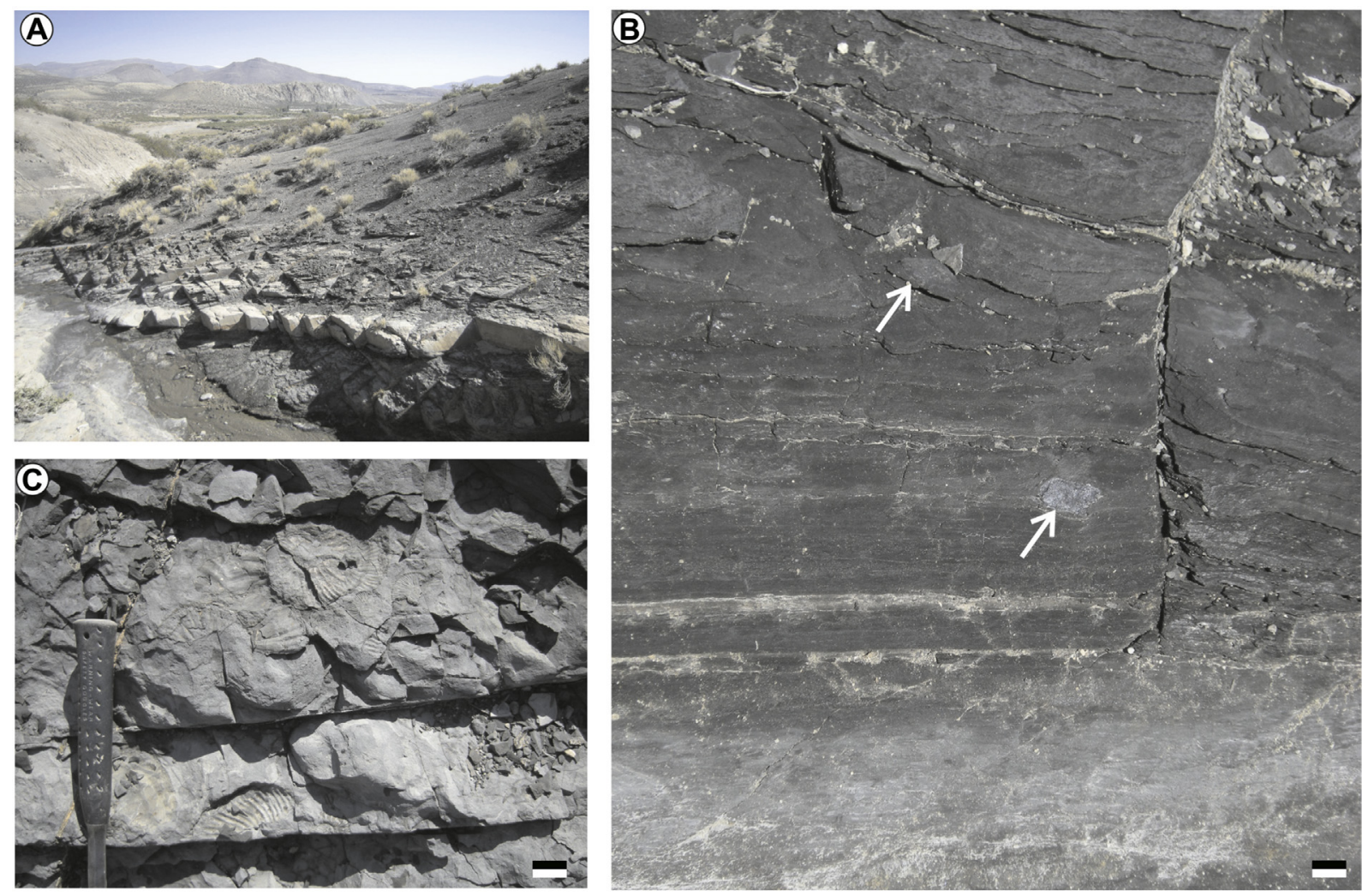

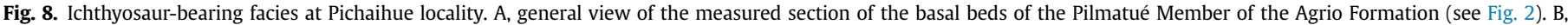

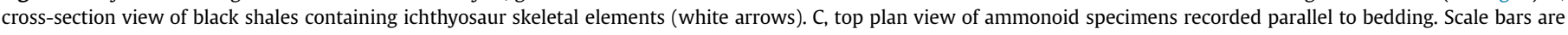
$1 \mathrm{~cm}$. 
4.3. Taphonomic mode 2: isolated ichthyosaur vertebral centra in dark-gray shales and fine-grained sandstones

Description. These records involve isolated vertebral centra (without neural arches), which are usually externally weathered and abraded, and also show some degree of fragmentation. Isolated ichthyosaur vertebral centra (MOZ-PV-6986, MOZ-PV-6998, and MOZ-PV-7000) were found embedded in tabular dark-gray shales, while MOZ-PV-6987 was found loose in a $10-\mathrm{cm}$ thick bed of finegrained grayish sandstones interbedded within a thick shale interval (Table 1). Fine bioturbation is recorded in shales while sandstones are usually highly bioturbated. Orientation of bones both in cross-section and plan-view is random. Associated fossils usually include isolated ammonoid and bivalve shells parallel to the bedding plane and small cementing oysters forming nests of aggregated specimens up to $40 \mathrm{~cm}$-thick and $1 \mathrm{~m}$ in lateral extension.

Interpretation. This mode of preservation probably resulted from the floating and eventually sinking of carcasses to a muddy or fine sandy seafloor under oxic to suboxic benthic conditions, resulting in parautochthonous preservation, with some degree of physical and biological reworking resulting in vertebral centra only. However, postmortem transport and disarticulation via drifting of bloated carcasses cannot be discarded in addition to decay and disarticulation after sinking on the seafloor. Scavenging and decomposition would result in the dispersal of skeletal elements, especially those from the periphery of the carcass (e.g., skull, neck, distal limbs). The torso would then undergo further decomposition and disarticulation on the sea floor. The fossil-bearing facies can be interpreted as deposited in proximal to distal offshore settings.

\subsection{Ichthyosaur occurrence in the second-order sequence stratigraphy framework}

Ichthyosaurs from the Agrio Formation were recorded in second-order TST and HST deposits (Fig. 3). The best preserved and most abundant specimens, including articulated remains, come from black shales of the TST of the Pilmatue Member of the Agrio Formation.

The base of the Pilmatué Member is characterized by a regional transgressive surface that covers most of the basin. The rising sea level from the Pacific Ocean flooded the basin from west to east (surpassing the volcanic arc of islands) creating new marine habitats towards the continent and enlarging the epeiric engulfment area. Thanks to the rising sea level, open-ocean dwelling fauna, especially nektonic and planktonic species, could easily pass through the volcanic arc of islands entering the back-arc basin and thus finding access to new niches and resources within the basin boundaries. This situation benefited not only ichthyosaurs, but probably also ammonoids, as most (though not all) of their immigration horizons coincided with sea-level transgressive intervals (Rawson, 2007), providing access to new niches and resources within the basin boundaries.

The TST is also linked with the best preservation of ichthyosaur remains among the studied records, including skeletal elements of a perinatal specimen. This is connected to the paleoenvironment and type of facies deposited during this interval. The TST is characterized, in the studied localities, by a basinal setting and black shale deposition which boosted the preservation of partially articulated skeletons. It would be desirable that these beds were prospected in detail in the future to look for more and better-preserved ichthyosaur specimens.

Poorly preserved ichthyosaur materials, i.e., isolated vertebral centra, were recorded in HST intervals in the Pilmatué and Agua de la Mula members, especially in the basal third of each HST (Fig. 3).
The HST forms when sediment accumulation rates exceed the rate of increase in accommodation space during high sea level stillstand. The stacking patterns exhibit prograding and aggrading clinoforms and shallower settings are progressively recorded from base to top. The fact that ichthyosaurs are restricted to the base of each HST is probably related to the presence of more distal settings at the onset of the tract, but disappearing rapidly due to the shallowingupwards trend. The poor preservation of these skeletal elements is due to physical and biological reworking on the seafloor, but lateral transport was probably low and thus they can be considered parautochthonous, as it is the case for benthic invertebrates of the unit (e.g., Lazo, 2006).

In contrast to ichthyosaurs, local plesiosaurians are present all along the second-order sequence composed by the Mulichinco and Agrio formations, including the LST, TST and HST (i.e., the middle Mendoza mesosequence). The fact that these reptiles were recorded throughout the depositional sequence is in line with the traditional, functional morphology-based life habit interpretation of long-necked plesiosaurs that suggests that they probably preferred shallower coastal habitats (Massare, 1988,1997a,b). Indeed, long-necked elasmosaurs are generally recorded in association with shallow marine (offshore/shelf to shoreface) environments, such as epicontinental seas, but also associated with marginal-marine settings such as barrier-island systems, estuaries and deltaic environments, all of them being more or less connected to the open sea (Hornung et al., 2013; Kear et al., 2006; Lazo and Cichowolski, 2003; O'Gorman et al., 2011, 2013; Sato et al., 2005). However, most findings in the Agrio Formation are associated with dark-gray shales that have been interpreted as proximal to distal offshore deposits (O'Gorman et al., 2015).

Therefore, it is clear that the Lower Cretaceous ichthyosaurs and plesiosaurs from the Neuquén Basin overlap their habitats, but only partially. Both groups inhabited the basinal and offshore settings, while the proximal outer shelf and inner shelf settings were inhabited by plesiosaurs only.

Another important issue to be considered relates to a recent finding by Cleary et al. (2015) suggesting that ichthyosaur completeness is highest during times of low sea level and deteriorates as sea level rises. In our case study, LST intervals did not provide any ichthyosaur records, despite intense collecting efforts. The difference between Cleary's et al. (2015) study and ours may be due to the fact that eustatic sea level changes, even when strong, can be counterbalanced by local or regional tectonic processes (e.g., Haq, 2014). For instance, a global high sea level may be locally compensated in a particular basin by tectonic uplift resulting in a local LST and, vice versa, a global low sea level could be counterbalanced by local subsidence of the basin floor. Indeed, during the mid Valanginian there is a trough in the global sea level curve (Haq, 2014, fig. 1), but in the Neuquén Basin a local rise in sea level is recorded as a TST followed by a HST. The study by Cleary et al. (2015) did not take into account these local or regional sea level changes and considered global (eustatic) sea level changes only. This is possibly why they had the unexpected result that ichthyosaur completeness is highest during times of low sea level and deteriorates as sea level rises.

\section{Conclusions}

Ichthyosaur remains from the Lower Cretaceous Agrio Formation, west-central Argentina, are systematically described and put in the broader context of their mode of occurrence and facies relationships. The studied records, encompassing the Valanginian-Hauterivian time-interval, are significant because this interval is particularly devoid of records worldwide and thus can be useful to understand how the ichthyosaurs were distributed in the 
Southern Hemisphere. Most records are incomplete and belong to isolated vertebral centra. The best preserved material (MOZ-PV6997/1-3) is represented by a series of seven partially articulated posterior thoracic vertebral centra of an adult individual found in close association with an ischiopubis (plus femur?) of an adult and a partially articulated fin and phalange elements of a perinatal specimen. This finding is important because it provides evidence of viviparity, suggesting the idea that ichthyosaurs would have been able to enter a back-arc basin from the Pacific Ocean to reproduce and give birth in epeiric seas, in a similar way to some modern large marine mammals, e.g., whales in Peninsula de Valdés (Patagonia, Argentina).

In the Neuquén Basin there are abundant records of ichthyosaurs from the Tithonian of the Vaca Muerta Formation and now the present evidence shows the occurrence of ichthyosaurs in the Valanginian-Hauterivian of the Agrio Formation. The apparent local absence of ichthyosaurs from Berriasian and early-middle Valanginian deposits may be due to the overall prevalence of shallower settings, especially associated with the top of the Vaca Muerta Formation and the Mulichinco Formation, that deterred the entrance of ichthyosaurs from the open ocean through the Andean volcanic arc.

The studied remains resulted from more than 20 years of collecting efforts; however, more prospection is needed in the black shales of distal localities such as Pichaihue and Arroyo Truquicó, where the best preserved specimens were found. The recovered specimens show a clear preservation bias: best-preserved specimens were collected from black shales while isolated bone elements and fragments were recorded from dark-gray shales and fine sandstones. Ichthyosaur records are also biased positively towards distally placed localities in the marine shelf of the Agrio Formation, being proximal (more coastal) localities negatively biased and devoid of records.

\section{Acknowledgements}

Valentin Fischer (University of Oxford and University of Liège) and an anonymous reviewer are thanked for their positive comments and suggestions that greatly improved the original manuscript. This work was supported by Agencia Nacional de Promoción Científica y Tecnológica [grants PICT 2013-1413, awarded to M.B. Aguirre-Urreta, and PICT 2015-1381 awarded to D.G. Lazo]. The studied ichthyosaur materials are the result of more than 20 years of periodic fieldwork on the Agrio Formation, and thus many colleagues and local people cooperated with us in prospecting and collecting in the field. Therefore, the authors wish to express their sincere gratitude to all of them. This is the contribution R-250 of the Instituto de Estudios Andinos "Don Pablo Groeber".

\section{References}

Aguirre-Urreta, M.B., Rawson, P.F., 2010. Lower Cretaceous ammonites from the Neuquén Basin, Argentina: the neocomitids of the Pseudofavrella angulatiformis Zone (upper Valanginian). Cretaceous Research 31, 321-343.

Aguirre-Urreta, M.B., Rawson, P.F., 2012. Lower Cretaceous ammonites from the Neuquén Basin, Argentina: A new heteromorph fauna from the uppermost Agrio Formation. Cretaceous Research 35, 208-216.

Aguirre-Urreta, M.B., Rawson, P.F., Concheyro, G.A., Bown, P.R., Ottone, E.G., 2005 Lower Cretaceous (Berriasian-Aptian) biostratigraphy of the Neuquén Basin. In: Veiga, G., Spalletti, L.A., Howell, J., Schwarz, E. (Eds.), The Neuquén Basin, Argentina: a case study in sequence stratigraphy and basin dynamics. Geological Society, London, pp. 57-81. Special Publications 252.

Aguirre-Urreta, M.B., Mourgues, F.A., Rawson, P.F., Bulot, L.G., Jaillard, E., 2007. The Lower Cretaceous Chañarcillo and Neuquén Andean basins: ammonoid biostratigraphy and correlations. Geological Journal 42, 143-173.

Aguirre-Urreta, M.B., Casadío, S., Cichowolski, M., Lazo, D.G., Rodríguez, D.L., 2008. Afinidades paleobiogeográficas de los invertebrados cretácicos de la cuenca Neuquina. Ameghiniana 45, 593-613.
Aguirre-Urreta, M.B., Lazo, D.G., Griffin, M., Vennari, V., Parras, A.M., Cataldo, C. Garberoglio, R., Luci, L., 2011. Megainvertebrados del Cretácico y su importancia bioestratigráfica. In: Leanza, H., Arregui, C., Danieli, J.C. (Eds.), Relatorio del XVIII Congreso Geológico Argentino: Geología y Recursos Naturales de la provincia del Neuquén. Asociación Geológica Argentina, Buenos Aires, pp. 465-488.

Aguirre-Urreta, M.B., Lescano, M., Schmitz, M., Tunik, M., Concheyro, A. Rawson, P.F., Ramos, V.A., 2015. Filling the gap: new precise Early Cretaceous radioisotopic ages from the Andes. Geological Magazine 152, 557-564.

Aguirre-Urreta, M.B., Schmitz, M., Lescano, M., Tunik, M.A., Rawson, P.F., Concheyro, A., Buhler, M., Ramos, V.A., 2017. A high precision U-Pb radioisotopic age for the Agrio Formation, Neuquén Basin, Argentina: Implications for the chronology of the Hauterivian Stage. Cretaceous Research 75, 193-204.

Allison, P., 1988. Konservat-Lagerstätten: cause and classification. Paleobiology 14 $331-344$.

Arkhangelsky, M.S., 2001. On a new ichthyosaur of the genus Otschevia from the Volgian Stage of the Volga Region near Ulyanovsk. Paleontological Journal 35, 629-634.

Bardet, N., 1994. Extinction events among Mesozoic marine reptiles. Historical Biology 7, 313-324.

Bardet, N., Falconnet, J., Fischer, V., Houssaye, A., Jouve, S., Pereda Suberbiola, X. Pérez-García, A., Rage, J.-C., Vincent, P., 2014. Mesozoic marine reptile palaeobiogeography in response to drifting plates. Gondwana Research 26, 869-887.

Baur, G., 1887. On the morphology and origin of the Ichthyopterygian. The American Naturalist 21, 837-840.

Behrensmeyer, A.K., 1991. Terrestrial vertebrate accumulations. In: Allison, P.A., Briggs, D.E.G. (Eds.), Taphonomy, Releasing the data locked in the fossil record, Topics in Geobiology 9. Plenum Press, New York, pp. 291-335.

Broili, F., 1907. Ein neüer Ichthyosaurus aus der norddeutschen Kreide. Palaeontographica 54, 139-162.

Cataldo, C.S., 2017. New records of marine gastropods from the Lower Cretaceous of west-central Argentina. Ameghiniana 54 (4), 405-440.

Chinsamy-Turan, A., 2005. The microstructure of dinosaur bones: deciphering biology through fine scale techniques. The Johns Hopkins University Press, Baltimore, p. 216.

Chinsamy, A., Raath, M.A., 1992. Preparation of fossil bone for histological examination. Palaeontographia Africana 29, 39-44.

Cichowolski, M., Lazo, D.G., 2000. Lower Cretaceous Marine Reptiles from Argentina. Thirty-first International Geological Congress, Río de Janeiro. August 6-17. Proceedings CD-ROM.

Cleary, T.J., Moon, B.C., Dunhill, A.M., Benton, M.J., 2015. The fossil record of ichthyosaurs, completeness metrics and sampling biases. Palaeontology 58, $521-536$.

De Blainville, H.M.D., 1835. Description de quelques espèces de reptiles de la Californie: précédée de l'analyse d'un système général d'erpétologie et d'amphibiologie. Nouvelles Annales du Muséum d'Histoire Naturelle 4, 233-296.

Delsett, L.L., Roberts, A.J., Druckenmiller, P.S., Hurum, J.H., 2017. A New Ophthalmosaurid (Ichthyosauria) from Svalbard, Norway, and Evolution of the Ichthyopterygian Pelvic Girdle. PLoS One 12 (1), e0169971. https://doi.org/ 10.1371/journal.pone.0169971.

Druckenmiller, P.S., Maxwell, E.E., 2014. A Middle Jurassic (Bajocian) ophthalmosaurid (Reptilia: Ichthyosauria) from the Tuxedni Formation, Alaska and the early diversification of the clade. Geological Magazine 151, 41-48.

Fernández, M.S., 1994. A new long-snouted ichthyosaur from the early Bajocian of Neuquén Basin (Argentina). Ameghiniana 31, 291-297.

Fernández, M.S., 1999. A New ichthyosaur from the Los Molles Formation (Early Bajocian), Neuquén Basin, Argentina. Journal of Vertebrate Paleontology 63, 677-681.

Fernández, M.S., 2003. Ophthalmosauria (Ichthyosauria) Forefin from the AalenianBajocian Boundary of Mendoza Province, Argentina. Journal of Vertebrate Paleontology 23, 691-694.

Fernández, M.S., 2007. Redescription and phylogenetic position of Caypullisaurus (Ichthyosauria: Ophthalmosauridae). Journal of Paleontology 81, 368-375.

Fernández, M., Aguirre-Urreta, M.B., 2005. Revision of Platypterygius hauthali von Huene, 1927 (Ichthyosauria: Ophthalmosauridae) from the Early Cretaceous of Patagonia, Argentina. Journal of Vertebrate Paleontology 25, 583-587.

Fernández, M.S., Campos, L., 2015. Ophthalmosaurids (Ichthyosauria: Thunnosauria): alpha taxonomy, clades and names. In: Fernández, M., Herrera, Y. (Eds.), Reptiles Extintos - Volumen en Homenaje a Zulma Gasparini, Publicación Electrónica de la Asociación Paleontológica Argentina 15. Asociación Paleontológica Argentina, Buenos Aires, pp. 20-30.

Fernández, M.A., Maxwell, E., 2012. The genus Arthropterygius Maxwell (Ichthyosauria: Ophthalmosauridae) in the Late Jurassic of the Neuquén Basin, Argentina. Geobios 45, 535-540.

Fernández, M.S., Talevi, M., Lazo, D.G., Cataldo, C.S., Aguirre-Urreta, M.B., 2015. Nuevos registros de ictiosaurios en la Formación Agrio, Cretácico Inferior de la Cuenca Neuquina. Reunión de Comunicaciones de la Asociación Paleontológica Argentina 2015. November 25-27. Actas, Mar del Plata, pp. 45-46.

Fischer, V., 2012. New data on the ichthyosaur Platypterygius hercynicus and its implications for the validity of the genus. Acta Palaeontologica Polonica 57, 123-134.

Fischer, V., 2016. Taxonomy of Platypterygius campylodon and the diversity of the last ichthyosaurs. PeerJ 4, e2604.

Fischer, V., Clement, A., Guiomar, M., Godefroit, P., 2011a. The first definite record of a Valanginian ichthyosaur and its implication for the evolution of post-Liassic Ichthyosauria. Cretaceous Research 32, 155-163. 
Fischer, V., Masure, E., Arkhangelsky, M., Godefroit, P., 2011b. A new Barremian (Early Cretaceous) ichthyosaur from Western Russia. Journal of Vertebrate Paleontology 31, 1010-1025.

Fischer, V., Maisch, M.W., Naish, D., Kosma, R., Liston, J., Joger, U., Krüger, F.J., Pardo Pérez, J., Tainsh, J., Appleby, R.M., 2012. New ophthalmosaurid ichthyosaurs from the European Lower Cretaceous demonstrate extensive ichthyosaur survival across the Jurassic-Cretaceous Boundary. PLoS One 7, e29234.

Fischer, V., Appleby, R.M., Naish, D., Liston, J., Riding, J.B., Brindley, S., Godefroit, P., 2013. A basal thunnosaurian from Iraq reveals disparate phylogenetic origins for Cretaceous ichthyosaurs. Biology Letters 9, 20130021. https://doi.org/ 10.1098/rsbl.2013.0021.

Fischer, V., Bardet, N., Guiomar, M., Godefroit, P., 2014. High diversity in Cretaceous ichthyosaurs from Europe prior to their extinction. PLoS One 9 (1). https://doi. org/10.1371/annotation/3b639689-59a3-4f4a-9ea0-11e9be043382. https://doi. org/10.1371/annotation/3b639689-59a3-4f4a-9ea0-11e9be043382.

Francillon-Vieillot, H., Buffrénil, V., de, Castanet, J., Géraudie, J., Meunier, F.J. Sire, J.Y., Zylberberg, L., de Ricqlès, A., 1990. Microstructure and mineralization of vertebrate skeletal tissues. In: Carter, J.G. (Ed.), Skeletal biomineralization: patterns, processes and evolutionary trends. Van Nostrand Reinhold, New York, pp. 471-530.

Groeber, P., 1946. Observaciones geológicas a lo largo del meridiano 70. I. Hoja Chos Malal. Revista de la Sociedad Geológica Argentina 1, 177-208.

Gulisano, C.A., Gutiérrez Pleimling, A.R., Digregorio, R.E., 1984. Análisis estratigráfico del intervalo Tithoniano-Valanginiano (Formaciones Vaca Muerta, Quintuco y Mulichinco) en el suroeste de la provincia de Neuquén. Noveno Congreso Geológico Argentino. November 5-9, San Carlos de Bariloche. Actas 1, pp. 221-235.

Haq, B., 2014. Cretaceous eustacy revisited. Global and Planetary Change 113 44-58.

Horner, J.R., Padian, K., de Ricqlès, A., 2001. Comparative osteohistology of some embryonic and perinatal archosaurs: developmental and behavioral implications for dinosaurs. Paleobiology 27, 39-58.

Hornung, J.J., Sachs, S., Kear, B.P., 2013. Sauropterygian fossils from the predominantly limnic-brackish Bückeberg Formation (Berriasian-Early Valanginian, Early Cretaceous) of northwestern Germany - diversity, distribution, and palaeoecology. In: Reitner, J., Yang, Q., Wang, Y., Reich, M. (Eds.), Palaeobiology and Geobiology of Fossil Lagerstätten through Earth History. Joint Conference of the "Paläontologische Gesellschaft" and the Palaeontological Society of China. September 23-27. Abstracts Volume, Universitätsverlag Göttingen, Göttingen, 75.

Howell, J.A., Schwarz, E., Spalletti, L.A., Veiga, G.D., 2005. The Neuquén Basin: An overview. In: Veiga, G.D., Spalletti, L.A., Howell, J.A., Schwarz, E. (Eds.), The Neuquén Basin, Argentina: A case study in sequence stratigraphy and basin dynamics, pp. 1-14. Geological Society of London Special Publications 252.

Kear, B.P. 2006. Marine reptiles from the Lower Cretaceous of South Australia: elements of a high-latitude cold-water assemblage. Palaeontology 49, 837-856.

Kear, B.P., Schroeder, N.I., Vickers-Rich, P., Rich, T.H., 2006. Early Cretaceous high latitude marine reptile assemblages from southern Australia. Paludicola 5 200-205.

Klein, N., Neenan, J.M., Scheyer, T.M., Griebeler, E.M., 2015. Growth patterns and lifehistory strategies in Placodontia (Diapsida: Sauropterygia). Royal Society Open Science 2, 140-440.

Kolb, C., Sander, P.M., 2009. Redescription of the ichthyosaur Platypterygius hercynicus (Kuhn 1946) from the Lower Cretaceous of Salzgitter (Lower Saxony, Germany). Palaeontographica Abteilung A Palaozoologie Stratigraphie 288, 151-192.

Lazo, D.G., 2006. Análisis tafonómico e inferencia del grado de mezcla temporal y espacial de la macrofauna del Miembro Pilmatué de la Formacion Agrio, Cretácico Inferior de cuenca Neuquina. Ameghiniana 43, 311-326.

Lazo, D.G., 2007. Análisis de biofacies y cambios relativos del nivel del mar en e Miembro Pilmatué de la Formación Agrio, Cretácico Inferior de cuenca Neuquina, Argentina. Ameghiniana 44, 73-89.

Lazo, D.G., Cichowolski, M., 2003. First plesiosaur remains from the Lower Cretaceous of the Neuquén Basin, Argentina. Journal of Paleontology 77, 784-789.

Lazo, D.G. Cichowolski, M., Rodríguez, D.L., Aguirre-Urreta, M.B., 2005. Lithofacies, palaeocology and palaeoenvironments of the Agrio Formation, Lower Cretaceous of the Neuquén Basin, Argentina. In: Veiga, G., Spalletti, L.A., Howell, J. Schwarz, E. (Eds.), The Neuquén Basin: a case study in sequence stratigraphy and basin dynamics, pp. 295-315. Geological Society of London Special Publication 252.

Leanza, H.A., Hugo, C.A., Repol, D., Gonzalez, R., Danieli, J.C., 2005. Hoja geológica 3969-I, Zapala, provincia del Neuquén. In: Boletín del Instituto de Geología y Recursos Minerales 275. Servicio Geológico Minero Argentino, Buenos Aires.

Legarreta, L., Gulisano, C.A., 1989. Análisis estratigráfico secuencial de la cuenca Neuquina (Triásico Superior-Terciario Inferior). In: Chebli, G.A., Spalletti, L.A (Eds.), Cuencas Sedimentarias Argentinas, pp. 221-243. Serie Correlación Geológica 6.

Legarreta, L., Kozlowski, E., 1984. Secciones condensadas del Jurásico - Cretácico de los Andes del sur de Mendoza: Estratigrafía y significado tectosedimentario. Noveno Congreso Geológico Argentino. November 5-9, San Carlos de Bariloche. Actas 1, pp. 286-297.
Legarreta, L., Uliana, M.A., 1991. Jurassic-Cretaceous marine oscillations and geometry of back-arc basin fill, central Argentine Andes. In: Macdonald, D.I.M. (Ed.), Sedimentation, Tectonics and Eustasy. International Association Sedimentologists, pp. 429-450. Special Publication 12.

Maisch, M.W., Matzke, A.T., 2000. The Ichthyosauria. Stuttgarter Beiträgezur Naturkunde Serie B. Geologie und Paläontologie 298, 1-159.

Massare, J.A., 1988. Swimming capabilities of Mesozoic marine reptiles: implications for method of predation. Paleobiology 14, 187-205.

Massare, J.A., 1997a. Swimming capabilities of Mesozoic marine reptiles: a review. In: Maddock, L., Bone, Q., Rayner, J.M.V. (Eds.), Mechanics and physiology of animal swimming. Cambridge University Press, Cambridge, pp. 133-149.

Massare, J.A., 1997b. Part IV: Faunas, behavior, and evolution. Introduction. In: Callaway, J.M., Nicholls, E.L. (Eds.), Ancient marine reptiles. Academic Press, pp. $401-421$.

Maxwell, E.E., Caldwell, M.W., 2003. First record of live birth in Cretaceous ichthyosaurs: closing an 80 million year gap. Proceedings of the Royal Society of London B 270 (Suppl.), S104-S107.

Maxwell, E.E., Caldwell, M.W., 2006. A new genus of ichthyosaur from the Lower Cretaceous of Western Canada. Palaeontology 49, 1043-1052.

McGowan, C., Motani, R., 2003. Handbook of Paleoherpetology. Part 8, Ichthyopterygia. Dr. Friedrich Pfeil, München.

Motani, R., 1999. On the evolution and homologies of ichthyopterygian forefins, Journal of Vertebrate Paleontology 19, 28-41.

O'Gorman, J.P., Salgado, L., Gasparini, Z., 2011. Plesiosaurios de la Formación Allen (Campaniano-Maastrichtiano) en el area del Salitral de Santa Rosa (Provincia de Río Negro, Argentina). Ameghiniana 48, 129-135.

O'Gorman, J.P., Salgado, L., Varela, J., Parras, A., 2013. Elasmosaurs (Sauropterygia, Plesiosauria) from La Colonia Formation (Campanian-Maastrichtian), Argentina. Alcheringa 37, 259-267.

O'Gorman, J.P., Lazo, D.G., Luci, L., Cataldo, C.S., Schwarz, E., Lescano, M., AguirreUrreta, M.B., 2015. New plesiosaur records from the Lower Cretaceous of the Neuquén Basin, west-central Argentina, with an updated picture of occurrences and facies relationships. Cretaceous Research 56, 372-387.

Pardo Pérez, J., Otero, R.A., Suárez, M.E., 2015. Síntesis del registro fósil de ictiosaurios (Reptilia: Ichthyosauria) en Chile. Publicación Ocasional del Museo Nacional de Historia Natural (Chile) 63, pp. 113-150.

Rawson, P.F., 2007. Global relationships of Argentine (Neuquén Basin) Early Cretaceous ammonite faunas. Geological Journal 42, 175-183.

Reboulet, S., Szives, O., Aguirre-Urreta, M.B., Barragán, R., Company, M., Idakieva, V., Ivanov, M., Kakabadze, M.V., Moreno-Bedmar, J.A., Sandoval, J., Baraboshkin, E.J., Caglar, M.K., Fözy, I., González-Arreola, C., Kenjo, S., Lukeneder, A., Raisossadat, S.N., Rawson, P.J., Tavera, J.M., 2014. Report on the 5th International Meeting of the IUGS Lower Cretaceous Ammonite Working Group, the "Kilian Group" (Ankara, Turkey, 31st August 2013). Cretaceous Research 50, 126-137.

Sato, T., Eberth, D.A., Nicholls, E.L., Manabe, M., 2005. Plesiosaurian remains from non-marine to paralic sediments. In: Currie, P.J., Koppelhus, E.B. (Eds.), Dinosaur Provincial Park, A Spectacular Ancient Ecosystem Revealed. Indiana University Press, Bloomington and Indianapolis, 249-176.

Schwarz, E., Buatois, L.A., 2012. Substrate-controlled ichnofacies along a marine sequence boundary: The Intra-Valanginian Discontinuity in central Neuquén Basin (Argentina). Sedimentary Geology 277-278, 72-87.

Schwarz, E., Howell, J.A., 2005. Sedimentary evolution and depositional architecture of a lowstand sequence set: the Lower Cretaceous Mulichinco Formation, Neuquén Basin, Argentina. In: Veiga, G., Spalletti, L.A., Howell, J., Schwarz, E. (Eds.), The Neuquén Basin: a case study in sequence stratigraphy and basin dynamics, pp. 109-138. Geological Society of London Special Publication 252.

Seilacher, A., Reif, W.-E., Westphal, F., 1985. Sedimentological, ecological and temporal patterns of Fossil-Lagerstatten. Philosophical Transactions of the Royal Society of London 311B, 5-23.

Spalletti, L.A., Poiré, D.G., Pirrie, D., Matheos, S.D., Doyle, P., 2001. Respuesta sedimentológica a cambios en el nivel de base en una secuencia mixta clástica-carbonática del Cretácico de la Cuenca Neuquina, Argentina. Revista Sociedad Geológica de España 14, 57-74.

Spalletti, L.A., Veiga, G.D., Schwarz, E., 2011. La Formación Agrio (Cretácico Temprano) en la Cuenca Neuquina. In: Leanza, H., Arregui, C., Danieli, J.C. (Eds.), Relatorio del XVIII Congreso Geológico Argentino: Geología y Recursos Naturales de la provincia del Neuquén. Asociación Geológica Argentina, Buenos Aires, pp. 145-160.

Stinnesbeck, W., Frey, E., Rivas, L., Pardo Pérez, J., Leppe Cartes, M., Salazar Soto, C. Zambrano Lobos, P., 2014. A Lower Cretaceous ichthyosaur graveyard in deep marine slope channel deposits at Torres del Paine National Park, southern Chile. Geological Society of American Bulletin 126 (9-10), 1317-1339.

Veiga, G.A., Spalletti, L.A., Howell, J.A., Schwarz, E., 2005. The Neuquén Basin, Argentina: a case study in sequence stratigraphy and basin dynamics. Geological Society of London Special Publication 252, p. 336.

von Huene, F., 1927. Beitrag zur Kenntnis mariner mesozoischer Wirbeltiere in Argentinien. Centralblatt für Mineralogie. Geologie und Paläontologie B 1927, $22-29$.

Weaver, C.E., 1931. Paleontology of the Jurassic and Cretaceous of West Central Argentina. Memoirs of the University of Washington, I. University of Washington Press, Seattle, 469 p., 62 pls. 